\title{
GENITALIAL MORPHOLOGY OF SOME EUPTEROTIDAE (LEPIDOPTERA) FROM SHIVALIKS IN INDIA
}

\author{
Rachita Sood ${ }^{1}$, H.S. Rose ${ }^{2}$ and P.C. Pathania ${ }^{3}$ \\ 1,2 Department of Zoology, Punjabi University, Patiala, Punjab 147002, India \\ ${ }^{3}$ Division of Entomology, Indian Agricultural Research Institute, New Delhi 110012, India \\ Email: ${ }^{3}$ pathaniapc@yahoo.co.in (corresponding author)
}

\begin{abstract}
External genitalial morphology of five species of Eupterotidae namely, Apona cashmirensis Kollar, Eupterote undata Blanchard, Eupterote assimilis Moore, Eupterote fraterna Moore, and Eupterote decorata Moore were studied and a key for their identification is presented in this paper.
\end{abstract}

\section{KEYWORDS}

Eupterotidae, genitalia, India, key, Lepidoptera.

Holloway (1987) mentions Eupteroidea as a small but most diverse tropical group of moths in Africa and the Oriental region. Moths belonging to this superfamily are characterized by the forewings possessing a series of indistinct waved lines (fasciations), out of which the double postmedial may be consistent. The hindwings too have such patterns which may be somewhat reduced and simple. All the fasciations may be clear or none may be clear, even in the specimens collected from the same locality (Hampson, 1892). During the course of the present study, a phenon comprising of 14 individuals were examined which belonged to the genus Eupterote Hübner, particularly because of typical wing pattern of multiple crenulate fasciations and a strong double postmedial line. The male genitalia of the type species, fabia Cramer has been given by Holloway (1987) and various constituent parts of the presently studied species, viz., Eupterote decorata Moore, E. undata Blanchard, E. fraterna Moore and E. assimalis Moore do possess bifid uncus diagnostically fused to the tegumen, gnathos absent, valva fused together basally to about onethird of their length, inner margin of the valvae being setose and corrugate, distal possession of each valva somewhat blunt and apex terminates into a slightly coiled narrow process. The vesica is tube-like. The genitalia of all the species, mentioned above, not only agree with the type species but are also congeneric to each other. However, these species can be very well differentiated on the basis of structure of the juxta and saccus. The present research deals with the five species i.e., Apona cashmirensis Kollar, Eupterote undata Blanchard, E, assimilis Moore, E, fraterna Moore, and E, decorata Moore while taking surveys-cum-collection tour to various localities in the Punjab Siwaliks. Besides giving an illustrated account of the genitalia, keys to their genera and species has also been furnished.
Description of external genitalia of species studied

Apona Walker

Apona Walker, 1856, List Specimens Lepid. Insects Colln. Br. Mus., $7: 1762$.

Type species: Apona pallida Walker, 1856, ibidem, $7: 1763$, by monotypy.

Apona cashmirensis Kollar

Apona cashmirensis Kollar, 1848, In Hügel Kashmir, 4 : 472, pl. 21 , fig. 4 .

\section{Material examined}

Two males, 25.vii.2000, Nangal, Roopnagar District, Punjab, 370m, coll. Rachita Sood \& P.C. Pathania

\section{Distribution}

North-West Himalayas and Sikkim (Hampson, 1892).

Male genitalia (Figs. 1 \& 2)

Uncus bifid, produced into lobes that are weakly setosed; gnathos tounge like; tegumen broad, simple, weakly sclerotised; vinculum U-shaped; saccus V-shaped, broad; valva well developed, elongated, narrow, costal margin arched slightly near base, gradually straightened towards apex, apex pointed, sacculus elongated, margin smooth, nearly straight; juxta squarish plate; aedeagus slender, strongly curved posteriorly, vesica tubular, armed with cornuti, cornuti small denticles like.
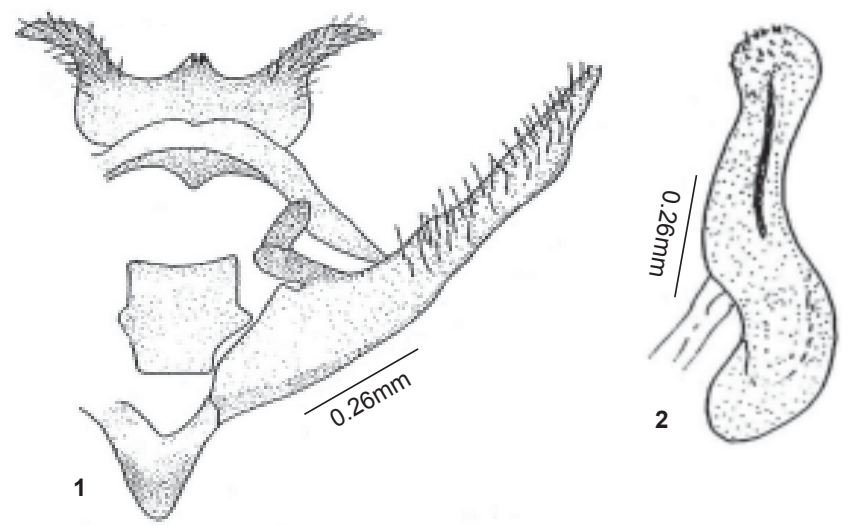

Figures 1-2. Apona cashmirenses Kollar 1 - Male genitalia: ventral view; 2 - Aedeagus

(C) Zoo Outreach Organisation; www.zoosprint.org Manuscript 1451; Received 13 October 2005; Revised received 06 March 2006; Finally accepted 26 April 2006 ; Date of publication 21 July 2006 
Female genitalia: Not examined.

Alar expanse: Male $114 \mathrm{~mm}$.

\section{Remarks}

Walker (1856) proposed the genus Apona with pallida from the Himalayan mountains as its type species. According to Fletcher and Nye (1982), this is a junior subjective synonym of Gastropacha cashmirensis Kollar. The genus Apona has been considered in Drepanulidae, Lasiocampidae (Moore, 1872) and Eupteroidea (Hampson, 1892) by the respective workers. The latter nomenclature is presently followed owing to its overall acceptance (Scoble, 1995). The species seems to be quite rare as per present collection records.

\section{Eupterote Hübner}

Eupterote Hübner (1820) 1816, Verz. bekannter Schmett.: 187.

Type species: Phalaena fabia Cramer, 1779, Uitlandsche kapellen (Papillions exot.), 3 : 98, pl. 250, fig. B, by subsequent designation by Moore [1883], 1882-3, Lepid. Ceylon, 2 : 141.

\section{Eupterote undata Blanchard}

Eupterote undata Blanchard, 1882. Jacq. Voy. Inde, Zool. Ins., 23, pl. 1, fig. 8 .

\section{Material examined}

Two males, 26.vi.2001, Dunera, Gurdaspur District, Punjab, 700m; one female, 5.vii.1999, PUP, Patiala District, Punjab, 250m, coll. Rachita Sood \& P.C. Pathania.

\section{Distribution}

Jabbalpore and Sikkim (Hampson, 1892).

Male genitalia (Figs. 3 \& 4)

Uncus bifid, diagnostically fused to the tegumen, both appear continuous; gnathos absent; tegumen broader fused to uncus, sclerotised; vinculum U-shaped; saccus thin, long, rod-like, slightly expanded basally; valvae fused together basally over one-third of length, inner margin setosed, corrugate, slightly blunt distally, coiled, narrower at apex, heavily sclerotised; juxta much elongated, reaching beyond vinculum; aedeagus highly ankylosed or fused to juxta; vesica tube like, slightly swollen, finely scobinated apically.

\section{Female genitalia (Fig. 5)}

Ovipositor lobes elongated, narrow, setosed; posterior apophyses shorter than the anterior apophyses; both apophyses strong, sclerotised, rod-like; ostium bursae ringlike, narrow, with sclerotised lobes on the lateral sides; ductus bursae elongated, narrow, wider towards corpus, slightly sclerotised; ductus seminalis originating just subbasally on the ductus bursae; corpus bursae globular, without signum.

Alar expanse: Male $94 \mathrm{~mm}$.

\section{Remarks}

The species is being reported for the first time from Punjab
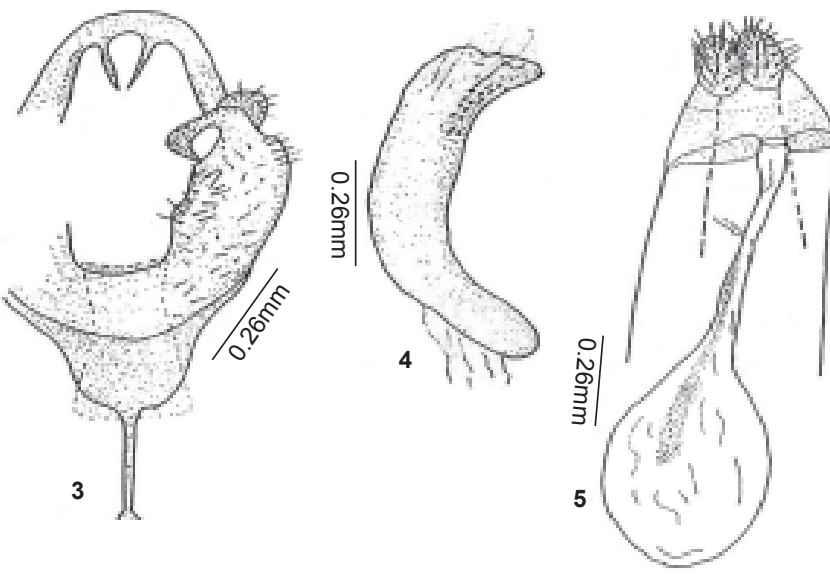

Figures 3-5. Eupterote undata Blanchard 3 - Male genitalia: ventral view; 4 - Aedeagus; 5 - Female genitalia

Shivaliks.

\section{Eupterote assimilis Moore}

Eupterote assimilis Moore, 1884. Trans. Ent. Soc., p. 363.

\section{Material examined}

Two males, 29.vi.1999; one male, 27.vii.1999, PUP, Patiala District, Punjab, 250m, coll. Rachita Sood \& P.C. Pathania.

\section{Distribution}

Dharamshala, northern India (Hampson, 1892).

\section{Male genitalia (Figs. $6 \& 7$ )}

Uncus bifid, teeth-like projection, heavily sclerotised, fused to tegumen; tegumen ring-like; vinculum U-shaped, given off into much elongated saccus; saccus not expanded (bulbous) basally; valva fused basally over one-third of the length, setosed, narrower apically, heavily sclerotised, blunt distally, distal process slightly curved, broad; juxta elongated not reaching beyond vinculum; aedeagus slightly arcurate, lower tip blunt; vesica tube like, finely scobinated apically.
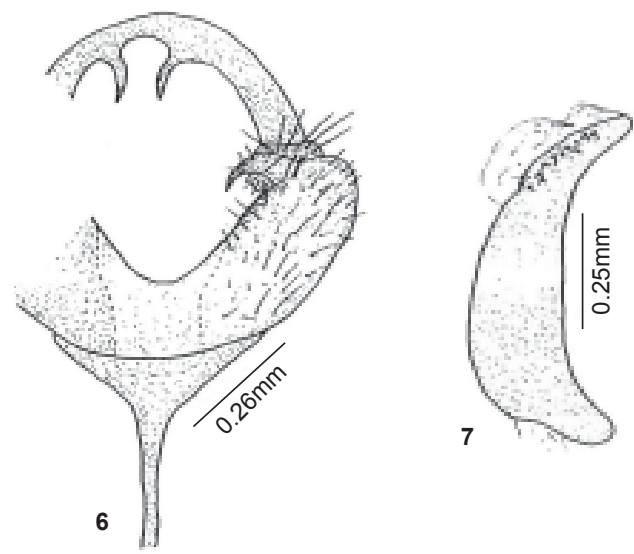

Figures 6-7. Eupterote assimilis Moore 6 - Male genitalia: ventral view; 7 - Aedeagus 
Female genitalia: Not examined.

Alar expanse: Male $81 \mathrm{~mm}$.

\section{Remarks}

The present collection is an additional distribution record for Punjab.

\section{Eupterote fraterna Moore}

Eupterote fraterna Moore, 1888, Proc. Zool. Soc. Lond., p. 406.

\section{Material examined}

Two males, 3.viii.1999, PUP, Patiala District, Punjab, 250m; one male, 4.viii.1999; two males, 7.viii.2000, Roopnagar, Punjab, 350m, coll. Rachita Sood \& P.C. Pathania.

\section{Distribution}

Dharamshala (Hampson, 1892).

Male genitalia (Figs. 8 \& 9)

Uncus bifid, diagnostically fused to the tegumen, uncus appears to be divided into teeth like projection, teths slender, short; gnathos absent; tegumen ring-like; vinculum broad Ushaped; saccus elongated; valva fused basally are one third of length, inner margin setosed, corrugate, slightly blunt distally, coiled, narrower at apex, apex curved, produced, heavily sclerotised; juxta not much elongated; aedeagus much arcurate apically, short, vesica finely scobinated apically.

Female genitalia: Not examined.

\section{Alar expanse: Male $84 \mathrm{~mm}$.}

\section{Remarks}

The species, under reference, is reported for the first time from Punjab Shivaliks.
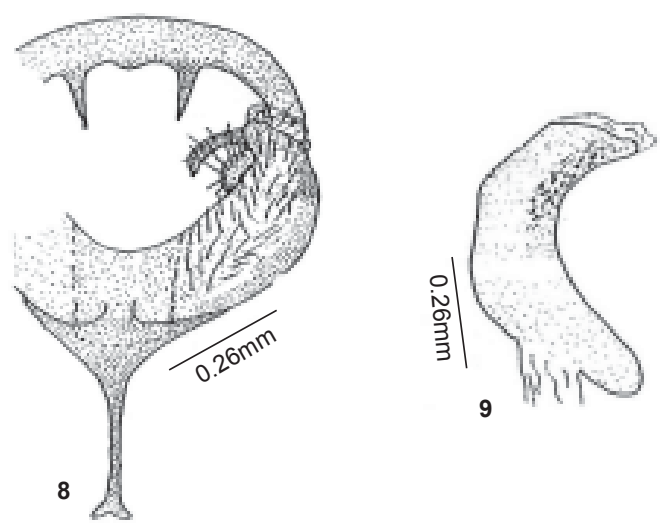

Figures 8-9. Eupterote fraterna Moore 8 - Male genitalia: ventral view; 9 - Aedeagus

\section{Eupterote decorata Moore}

Eupterote decorata Moore, 1884. Trans. Ent. Soc., p. 309.

\section{Material examined}

Two males, 4.viii.1999; one male, 18.viii.2003, PUP, Patiala District, Punjab, 250m, coll. Rachita Sood \& P.C. Pathania.

\section{Distribution}

Punjab (Hampson, 1892).

\section{Male genitalia (Figs. $10 \& 11$ )}

Uncus bifid, teeth like projections, fused to tegumen; much elongated and broad; vinculum U-shaped, broader; saccus elongated, rod-like, posterior base slightly swollen; valvae fused basally to one-third of length, inner margin setosed, corrugate, slightly blunt distally, curved apically, apex heavily sclerotised; juxta small cup like; aedeagus not arcurate, nearly straight apically, vesica tube like, finely scobinated apically.

\section{Key for the separation of species studied}

The following key has been prepared for the separation of species covered in the present study:

1. Labial palpus long, heavily fringed with hairs; male genitalia with gnathos present; valvae well developed, saccus V-shaped......

Apona Walker

$1 \mathrm{~A} \quad$ Labial palpus short, not so heavily fringed with hairs; male genitalia with gnathos absent; valvae reduced, saccus thin, much elongated, rod-shaped

Eupterote Hübner

\section{Key to the Indian species of the genus Eupterote Hübner}

1. Ground colour slightly redder; female with ground colour redder or yellow; male genitlaia with uncus process comparatively more developed; juxta much elongated, reaching beyond vinculum.

undata Blanchard

$1 \mathrm{~A} \quad$ Ground colour never redder in tinge; male genitalia with uncus process comparatively less developed; juxta never reaching beyond vinculum

2. Ground colour slightly pale cinnamon brown, collar tinged yellow; male genitalia with saccus not expanded or bulbous basally; valva with distal process slightly curved, broad.

assimilis Moore

2A Ground colour not cinnamon brown; collar never tinged yellow; male genitalia with saccus expanded basally; valva with distal process much curved, narrow.

3 Ground colour vinous-brown, the irregular crenulated waved lines weak or nearly obsolescent; male genitalia with tegumen ring-like; aedeagus much arcurate apically......

3A Ground colour sulphur yellow; irregular crenulated waved lines much conspicuous dark brown in colour; male genitalia with tegumen elongated; aedeagus not arcurate, nearly straight apically....... decorata Moore 
Genitalial morphology .....

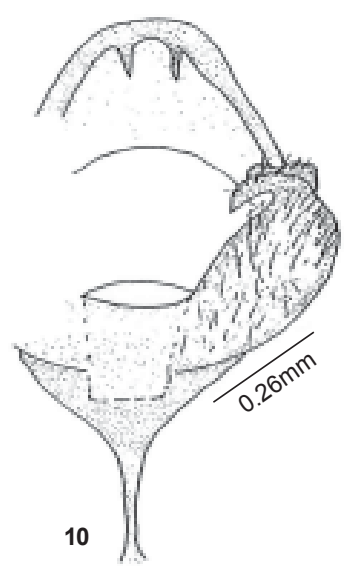

Figures 10-11 Eupterote decorata Moore 10 - Male genitalia: ventral view; 11 - Aedeagus

Female genitalia: Not examined.

Alar expanse: Male $90 \mathrm{~mm}$.

\section{Remarks}

Hampson (1892) recorded the species from the then Punjab including Himachal Pradesh and Haryana and did not mention any precise locality. Its collection from the aforesaid locality is an actual place of its availability in the present Punjab.

\section{ReFERENCES}

Fletcher, D.S. and I.W.B. Nye (1982). The Generic Names of Moths of World. Vol. 4. London. British Museum (Natural History), 243pp.

Hampson, G.F. (1892). Fauna of British India including Ceylon and Burma: Moths, 1: Taylor and Francis Ltd., London, 527pp.

Holloway, J.D. (1987). The Moths of Borneo. Part 3. Lasiocampidae, Bombycidae, Brahmadidae, Saturniidae, Sphingidae, Southdene Edn. Bhd. Kuala Lampur, Malaysia.

Moore, F. (1872). Descriptions of new India Lepidoptera. Proceedings of the Zoological Society of London 1872: 581-582.

Scoble, M.J. (1995). The Lepidoptera form, function and Diversity. Oxford University Press, xi+404pp.

Walker, F. (1856). List of the specimens of the Lepidoptera insects in the collection of British Museum. Transactions of the Entomological Society of London 9: 147.

\section{ACKNowledgement}

Dr. H.S. Rose is grateful to the Punjab State Council of Science and Technology, Chandigarh for funding the project on biodiversity of moths and to the Vice-Chancellor, Punjabi University, Patiala for providing necessary facilities. Authors would like to thank Dr. J.R.B. Alfred (Director), ZSI, Calcutta and Dr. V.V. Ramamurthy (Principal Scientist), Museum incharge, IARI, New Delhi and Dr. H.R. Khan (Head), FRI, Dehradun for giving the permission to visit their respective museum.

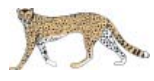

\section{BOOK NOTICE}

\section{AN INTRODUCTION TO TAXONOMY}

by

\section{T. C. NARENDRAN}

2006

Zoological Survey of India, 234/4 A, J.C. Bose Road, 2nd M.S.O. Building, Kolkata, West Bengal 7000020, India

Pages: 80; Price: Rs. 100/-

Foreword by J.R.B. Alfred, Director, ZSI

Introduction

Chapter 1 - Taxonomy and its importance

-- in biodiversity and conservation, research and studies, medicine, agriculture and pest management, quarantine, national defense, fisheries, parasitology and veterinary science, conservation of plants and animals; identification of pest and natural enemies; culture contamination; misidentification; collections \& literature in pest management

Chapter 2 - Taxonomic impediments and problems to overcome -- introduction; impediments for building up taxonomic collections and its maintenance, publishing taxonomic work; shortage of manpower; lack of funding for taxonomic research, training in taxonomy, library facilities; international cooperation; development of taxonomic centres; need for efficient international networking; taxasphere and inventorying; the desired end product

\section{Chapter 3 - Taxonomic collections and collecting}

-- method of collection; labelling; preservation and curation of collections; cataloguing collections; kinds of collections; exchange of collections

\section{Chapter 4 - Identification}

-- identification using taxonomic keys; comparing the identified specimen with previous description, with authenticated specimens; requesting help from specialists; identification through internet

\section{Chapter 5 - Classification}

-- history of classification; kinds of classification - downward, horizontal and vertical, natural, cladistic or phylogenetic, phenetic, evolutionary, biological, omnispective, hierarchical; units of classification; the process of ranking

\section{Chapter 6 - Approaches in taxonomy}

-- external morphology; approaches based on anatomy, developmental biology, molecular taxonomy and biochemical, karyology, numerical taxonomy, ecological and ethological

\section{Chapter 7 - Nomenclature}

-- history of Nomenclature; the nature of scientific names; species and infraspecies names; genus group taxa; synonyms and homonyms; meaning of Authors name in brackets; the law of priority; rejection of names; names of hybrid plants; tautonyms; nomen novum or replacement name; preoccupied names; biocode; the type and its importance; kinds of types; type designation

\section{Chapter 8 - Publication}

-- kinds of publications - short research papers, revision, monograph, faunal/floral works, synopsis and reviews, handbooks and manuals, catalogues and checklists, atlases; major features of taxonomic publications; preparation

\section{Chapter 9 - Ethics in taxonomy}

-- credit; lending and borrowing of specimens; loan of material; exchange of materials; collaboration and cooperation with fellow researchers; use of language; ethics of taxonomic publication; authorship; correspondence; taxonomists and user communities; suppression of relelvant details

Acknowledgements

Glossary related to taxonomy

References 